\title{
LITTLE CIRCLE ARABIC LEARNING (LCAL) BERBASIS TUTOR SEBAYA UNTUK PEMBELAJARAN BAHASA ARAB DI PERGURUAN TINGGI
}

\author{
Lailatul Mauludiyah \\ Universitas Muhammadiyah Malang \\ email: elimauludiyah@umm.ac.id
}

\begin{abstract}
Nowadays, there are many problems in using methods found by higher students in the teaching and learning process of the Arabic language, for that it is necessary to have an update in the learning method. The purpose of this study is to develop a peer tutoring based Arabic learning model. From this development, it is expected to be a solution to the survey on the Arabic learning system in the Arabic Language Teaching Program, and the learning system is still classical. The classical learning model is less attractive to students. Because what happens is one-way communication. While the ideal language teaching is to use two-way communication, and students are more active. Also, the problem of class management is a concern. Language learning using large classes is considered less effective. This study uses a qualitative approach to explain the results of validation from media experts and learning methods. The stages of data analysis in this study are data reduction, data presentation, conclusion drawing. This LCAL learning model is developed through constructivism theory and peer tutoring methods. Which lecturer will work with students who have a high ability to manage the class, and the class used is a small class with 10 class members. The output of this study is a recommendation of the Arabic learning model to create a pleasant and not boring foreign language learning atmosphere so that it can achieve the desired Arabic learning target.
\end{abstract}

Keywords: Arabic Learning; Little Circle; Peer Tutoring.

\begin{abstract}
Abstrak
Pembelajaran Bahasa Arab di Perguruan Tinggi hingga saat ini masih mengalami problem di metode pembelajaran, untuk itu perlu adanya pembaharuan dalam metode pembelajaran. Tujuan dari penelitian ini adalah untuk mengembangkan model pembelajaran bahasa Arab berbasis tutor sebaya. Dari perkembangan ini diharapkan dapat menjadi solusi untuk survei tentang
\end{abstract}




\begin{abstract}
sistem pembelajaran bahasa Arab di Program Pengajaran Bahasa Arab, sistem pembelajarannya masih klasik. Model pembelajaran klasik kurang menarik bagi siswa. Karena yang terjadi adalah komunikasi satu arah. Sedangkan pengajaran bahasa yang ideal adalah menggunakan komunikasi dua arah dan siswa lebih aktif. Juga, masalah manajemen kelas menjadi perhatian. Pembelajaran bahasa menggunakan kelas besar dianggap kurang efektif. Penelitian ini menggunakan pendekatan kualitatif untuk menjelaskan hasil validasi dari para ahli media dan metode pembelajaran. Tahapan analisis data dalam penelitian ini adalah reduksi data, penyajian data, penarikan kesimpulan. Model pembelajaran LCAL ini dikembangkan melalui teori konstruktivisme dan metode tutor sebaya. Dosen mana yang akan bekerja dengan mahasiswa yang memiliki kemampuan tinggi mengelola kelas dan kelas yang digunakan adalah kelas kecil dengan 10 anggota kelas. Output dari penelitian ini adalah rekomendasi dari model pembelajaran bahasa Arab untuk menciptakan suasana belajar bahasa asing yang menyenangkan dan tidak membosankan sehingga dapat mencapai target pembelajaran bahasa Arab yang diinginkan.
\end{abstract}

Kata Kunci: Little Circle; Pembelajaran Bahasa Arab; Tutor Sebaya.

\title{
A. Pendahuluan
}

Pembelajaran bahasa bagi penutur asing memang menjadi hal yang menarik dan banyak diminati oleh semua kalangan. Banyaknya minat tersebut menjadi tantangan tersendiri bagi para pengajar bahasa asing untuk terus mengembangkan hal-hal yang berkaitan dengan pembelajaran. Pembelajaran bahasa kedua bagi non penutur bahasa tersebut diperlukan banyak kreativitas. Karena mayoritas dari para pembelajar bahasa asing utamanya bahasa Arab, aktivitas tersebut hanyalah sebuah tuntutan sementara dan bukan merupakan kebutuhan. Selama ini, persepsi bahasa Arab sebagai asing masih tergeser dengan bahasa Inggris.

Menurut survei pada sistem pembelajaran bahasa Arab di Program Pembelajaran Bahasa Arab (PPBA) Universitas Muhammadiyah Malang sistem pembelajarannya masih bersifat klasikal. Program yang dikhususkan untuk seluruh mahasiswa Fakultas Agama Islam (FAI) tersebut kurang diminati oleh mahasiswa terutama mahasiswa program studi Pendidikan Bahasa Arab. Berdasarkan perhitungan kehadiran mahasiswa program studi PBA selama tiga bulan, dari 60 mahasiswa hanya 50 persen dari mahasiswa aktif mengikuti kegiatan pembelajaran di PPBA, sementara 40 persen, kehadirannya pada pembelajaran kadang-kadang. Sementara 5 persen dari mahasiswa tidak hadir sama sekali tapi masih terhitung mahasiswa aktif, dan 5 persen terhitung siswa non aktif.

Berdasarkan hasil wawancara kepada mahasiswa yang tergolong kadang-kadang dalam mengikuti pembelajaran PPBA, pembelajaran di PPBA terkadang terkesan membosankan, dan para mahasiswa tersebut merasa akan mendapat hal serupa dalam kurikulum program studi. Selain itu, beberapa mahasiswa juga mengatakan, kedatangan mereka pada program 
PPBA tersebut hanya sebatas memenuhi kewajiban karena merupakan program fakultas.

Namun hal serupa, tidak hanya terjadi pada program studi Pendidikan Bahasa Arab saja. Pada tiga program studi yang lain juga sama. Alasannya adalah beberapa mahasiswa yang tidak pernah hadir dalam program tersebut karena mereka merasa memiliki kapabilitas di bidang bahasa Arab, utamanya mahasiswa yang berada di kelas level bawah.

Permasalahan di atas, tidak hanya terjadi di Universitas Muhammadiyah Malang saja namun juga terjadi di perguruan tinggi lainnya. Beberapa solusi yang sudah dilakukan untuk menangani masalah tersebut adalah menggunakan pendekatan scientific $^{1}$, memperjelas tujuan kurikulum $^{2}$, menggunakan student center $^{3}$, dan lain-lain. Untuk itu, penelitian ini akan mengembangkan model pembelajaran berbasis tutor sebaya dan akan menjadi satu solutif dalam sistem pembelajaran di PPBA. Sebab, pada sistem pembelajaran Little Circle Arabic Learning (LCAC) ini akan mengakomodir kemampuan berbahasa mahasiswa di Fakultas Agama Islam utamanya program studi pendidikan Bahasa Arab, sehingga persepsi kesia-siaan dalam mengikuti sistem pembelajaran dalam program PPBA akan hilang.

Little Circle Arabic Learning ini merupakan pengembangan dari model pembelajaran tutor sebaya yang mana mahasiswa dengan nilai akademik yang lebih tinggi mempunyai tanggung jawab sebagaimana dosen dalam penyampaian materi pembelajaran. Namun, dosen tidak lepas tanggung jawab dalam pelaksanaan pembelajaran. Proses pembelajaran tetap dalam supervisi dari dosen sebagai penanggung jawab pelaksana materi. Perlunya pengembangan model pembelajaran ini, untuk mengatasi kesan monoton dan membosankan dalam pembelajaran Bahasa Arab.

Pada penelitian yang pernah ada, menggabungkan beberapa model pembelajaran tutor sebaya dengan yang lain dan mengintegrasikan langsung pada empat maharah dengan menggunakan model tutor sebaya tersebut belum ada konsep jelas pengembangannya. Pada penelitian yang akan dilakukan ini, akan mengembangkan model pembelajaran dengan mengacu

\footnotetext{
${ }^{1}$ Buhori Muslim, "Konsep Scientific Approach Dalam Pembelajaran Bahasa Arab Di Perguruan Tinggi (Upaya Meningkatkan Produktivitas, Kreativitas dan Inovasi Mahasiswa Dalam Pembelajaran)," LISANUNA: Jurnal IImu Bahasa Arab dan Pembelajarannya 5, no. 1 (2016): 105, https://jurnal.ar-raniry.ac.id/index.php/lisanuna/article/view/858.

2 Fatwiah Noor, "Kurikulum Pembelajaran Bahasa Arab di Perguruan Tinggi," Arabiyatuna : Jurnal Bahasa Arab 2, no. 1 (2018): 1-22, https://doi.org/10.29240/jba.v2i1.305.

${ }^{3}$ M. Arif Kurniawan, Agus Miftahillah, dan Nilna Milhatan Nasihah, "Pembelajaran Berbasis Student-Centered Learning Di Perguruan Tinggi: Suatu Tinjauan Di UIN Sunan Kalijaga Yogyakarta," Lentera Pendidikan : Jurnal IImu Tarbiyah dan Keguruan 21, no. 1 (2018): 1-11, https://doi.org/10.24252/Ip.2018v21n1i1.
} 
pada teori konstruktivisme dengan menggunakan small classs dalam pembelajaran. Pembelajaran Bahasa Arab dengan Small Class, khususnya di perguruan tinggi sangat jarang sekali. Kebanyakan dari perguruan tinggi, kurang memperhatikan jumlah mahasiswa dalam satu kelasnya untuk pembelajaran. Sehingga penelitian ini bisa menjadi solusi pada pembelajaran Bahasa Arab di perguruan tinggi.

\section{B. Kajian Teori \\ 1. Teori Pembelajaran Tutor Sebaya}

Tutor sebaya merupakan salah satu strategi pembelajaran untuk membantu memenuhi kebutuhan peserta didik. Rasa saling menghargai dan mengerti dibina di antara peserta didik melalui kerja sama. Tutor sebaya akan merasa bangga atas perannya dan juga belajar dari pengalamannya. Hal ini membantu memperkuat apa yang telah dipelajari dan diperoleh atas tanggung jawab yang dibebankan kepadanya. Ketika mereka belajar dengan "tutor sebaya" peserta didik juga mengembangkan kemampuan yang lebih baik untuk mendengarkan, berkonsentrasi, dan memahami apa yang dipelajari dengan cara yang bermakna. ${ }^{4}$

Tutor sebaya dikenal dengan pembelajaran teman sebaya atau antar peserta didik, hal ini bisa terjadi ketika peserta didik yang lebih mampu menyelesaikan pekerjaannya sendiri dan kemudian membantu peserta didik lain yang kurang mampu dalam menyelesaikan pekerjaannya. Tutor Sebaya merupakan salah satu strategi pembelajaran untuk membantu memenuhi kebutuhan peserta didik. Ini merupakan pendekatan kooperatif bukan kompetitif. Rasa saling menghargai dan mengerti dibina di antara peserta didik yang bekerja sama. ${ }^{5}$

Penerapan model tutor sebaya dapat memberikan motivasi dan mendorong peserta didik menjadi aktif dalam proses pembelajaran sehingga peserta didik tidak hanya diam, mencatat, dan mendengarkan ceramah dari guru, melainkan peserta didik akan terlibat secara aktif dalam proses pembelajaran bersama dengan tutor dan anggota lain dalam kelompoknya. ${ }^{6}$

\footnotetext{
${ }^{4}$ Niken Sholi Indrianie, “Penerapan Model Tutor Sebaya Pada Mata Pelajaran Bahasa Inggris Reported Speech Terhadap Hasil Belajar Peserta Didik MAN Kota Probolinggo," Jurnal Kebijakan Dan Pengembangan Pendidikan 3, no. 1 (2015), http://ejournal.umm.ac.id/index.php/jkpp/article/view/2210.

${ }^{5}$ Maria Ulfah, "Optimalisasi Hasil Belajar IPA Tentang Sistem Gerak Pada Manusia Melalui Metode Diskusi Dengan Tehnik Pembelajaran Tutor Sebaya," Jurnal Pendidikan Tindakan Kelas 3, no. 1 (2012), https://i-rpp.com/index.php/dinamika/article/view/5.

${ }^{6}$ Indrianie, "Penerapan Model Tutor Sebaya Pada Mata Pelajaran Bahasa Inggris Reported Speech Terhadap Hasil Belajar Peserta Didik MAN Kota Probolinggo.”
} 
Pembelajaran dengan metode tutor sebaya memberikan kebebasan kepada siswa yang menjadi tutor untuk mengembangkan metode dalam menjelaskan materi kepada teman-temannya. Kondisi pembelajaran yang difasilitasi oleh teman sebaya yang akrab akan membuat tutee mengikuti kegiatan pembelajaran lebih efektif. ${ }^{7}$ Selain itu, dalam proses pembelajaran dengan menggunakan metode tutor sebaya ini terjadi proses membangun dan memberitahukan pengetahuan. Seorang tutor dalam kelompok akan mendapatkan manfaat ketika dia memberikan penjelasan kepada tutee-nya. Ketika tutor memberikan penjelasan pada tutee, tutor melakukan pengintegrasian konsep dan prinsip serta memunculkan ide baru. ${ }^{8}$ Hal semacam ini ketika seseorang mempunyai kedekatan secara biologis akan mampu menjelaskan apa yang dimaksud, dan komunikasi tentang pengetahuan lebih mudah.

Berdasarkan hasil penelitian, metode pembelajaran tutor teman sebaya ini akan meningkatkan tingkat pemahaman mahasiswa terhadap tugas belajar yang diberikan. Hal ini terlihat dari waktu belajar yang digunakan pada kelompok perlakuan. Mereka selesai tepat waktu dan penyelesaian tugas lebih cepat dibandingkan kelompok kontrol dengan model pembelajaran konvensional. ${ }^{9}$

\section{Pembelajaran dalam Kelompok Kecil}

Hasil penelitian berkenaan dengan kemampuan siswa dalam memahami dan menyampaikan pandangan kepada teman sebaya menunjukkan bahwa sebagian besar siswa telah mencapainya dengan sangat baik. Kemampuan dalam memahami dan menyampaikan pandangan tersebut merupakan suatu hal yang sangat penting bagi perkembangan sosial remaja. ${ }^{10}$ Menurut Syamsu Yusuf bahwa dengan bergaul dengan teman sebaya yang sama jenis maupun berbeda jenis

\footnotetext{
${ }^{7}$ Ruseno Arjanggi dan Titin Suprihatin, "Metode Pembelajaran Tutor Teman Sebaya Meningkatkan Hasil Belajar Berdasar Regulasi-Diri," Makara Human Behavior Studies in Asia 14, no. 2 (2010): 91-97, https://doi.org/10.7454/mssh.v14i2.666.

${ }^{8}$ Rod D. Roscoe dan Michelene T. H. Chi, “Understanding Tutor Learning: Knowledge-Building and Knowledge-Telling in Peer Tutors' Explanations and Questions:," Review of Educational Research 77, no. 4 (2007), https://doi.org/10.3102/0034654307309920.

${ }^{9}$ Arjanggi dan Suprihatin, "Metode Pembelajaran Tutor Teman Sebaya Meningkatkan Hasil Belajar Berdasar Regulasi-Diri."

${ }^{10}$ Zadrian Ardi, Yulidar Ibrahim, dan Asrul Said, "Capaian Tugas Perkembangan Sosial Siswa Dengan Kelompok Teman Sebaya Dan Implikasinya Terhadap Program Pelayanan Bimbingan Dan Konseling," Konselor 1, no. 2 (2012), https://doi.org/10.24036/0201212522-0-00.
} 
kelamin, remaja akan belajar berbagai keterampilan-keterampilan sosial di antaranya adalah keterampilan dalam berkomunikasi. ${ }^{11}$

Kelas kecil didefinisikan sebagai kelas yang jumlah siswanya tidak lebih dari 20 orang. Kelas kecil adalah hasil reduksi sebuah kelas (class size). Ukuran kelas dapat mempengaruhi performa siswa apabila besarnya berubah. Dalam penelitian istilah kelas kecil digunakan untuk penyebutan suatu kelompok kecil dari reduksi sebuah kelas besar.

\section{Metode Penelitian}

Penelitian ini menggunakan pendekatan kuantitatif dengan penelitian jenis Research and Development (R\&D). Dalam penelitian ini mengembangkan model pembelajaran Bahasa Arab. Penelitian ini dilaksanakan selama dua periode, periode pertama sebagai proses penguatan desain pengembangan model pembelajaran. Dan tahun kedua uji coba massal dari hasil pengembangannya. Penelitian pengembangan yang akan digunakan ini menggunakan model ADDIE yaitu Analyze, Design, Develop, Implement, Evaluate. Dengan langkah-langkah sebagai berikut: (1) Observasi awal dan pengumpulan data awal. (information collecting), dalam tahapan ini, peneliti mengumpulkan data awal dan menghimpun permasalahan di lapangan. (2) Pengembangan draf produk (model pembelajaran), membuat draf model pembelajaran LCAL dengan menyesuaikan pada permasalahan yang terjadi di lapangan. (3) Validitas produk Melakukan validitas konstruk terhadap produk kepada ahli. Dalam hal ini, validator dari pengembangan model pembelajaran ini adalah (a) Dr. Abdul Haris, MA (b) Ahmad Fathoni, Lc., M.Ag, (c) Dr. H. Muhammad Ahda Arafat, M.A, (d) Hermi Ismawati, S.S., M.Pd.I. (4) Uji coba tahap pertama (skala kecil), (5) Merevisi produk, (6)Uji coba lapangan kedua, (7) Penyempurnaan produk, (8) Implementasi.

Metode pengumpulan data pada penelitian ini adalah (1) observasi partisipatif yang mana peneliti langsung memberikan perilaku kepada mahasiswa (responden). Dan hasil observasi direkam dalam lembar observasi. Hasil dari observasi ini sebagai data pendukung fakta di lapangan sebelum dan sesudah pelaksanaan model pembelajaran. Pada observasi ini, akan menilai motivasi kehadiran dan keseriusan mahasiswa dalam pelaksanaan pembelajaran. (2) Angket, pada penelitian ini digunakan untuk menilai desain model pembelajaran yang dilakukan oleh validator. Jenis angket yang digunakan adalah campuran lima item untuk menilai kualitas desain model pembelajaran. Dan satu item bersifat terbuka untuk komentar umum validator tentang model pembelajaran.

${ }^{11}$ Syamsu Yusuf, Psikologi Perkembangan Anak Dan Remaja (Bandung: PT. Remaja Rosda Karya, 2011), h. 158. 
Sementara Analisis data pada penelitian ini menggunakan pendekatan kualitatif dengan langkah analisis data dengan (1) reduksi data, pada tahap ini merangkum, memilih hal-hal yang pokok, memfokuskan pada hal-hal yang penting. Data yang didapat adalah data hasil observasi dan penilaian dari validator. (2) Penyajian data. Dalam tahap ini, dilakukan pemaparan data yang sudah direduksi pada tahap pertama. (3) Penarikan kesimpulan pada bagian ini peneliti mengutarakan kesimpulan dari data-data yang telah diperoleh. Kegiatan ini dimaksudkan untuk mencari makna data yang dikumpulkan dengan mencari hubungan, persamaan, atau perbedaan.

\section{Hasil dan Pembahasan}

Sebelum melakukan penyusunan draf pengembangan model pembelajaran, dilakukan survei kepada mahasiswa PPBA di Fakultas Agama Islam. Untuk objek penelitian berjumlah 51 mahasiswa dari program studi PAI, PBA, dan HKI dan Ekonomi Syariah. Pada angket yang tersebar, terdapat lima pertanyaan tentang model pembelajaran yang sedang berlangsung di PPBA dengan hasil angket pada tabel 1

Tabel 1. Hasil Angkat Mahasiswa Sebelum Mengembangkan

\begin{tabular}{|c|c|c|c|}
\hline No & Pernyataan & \multicolumn{2}{|c|}{ Jumlah Jawaban } \\
\hline \multirow[t]{5}{*}{1} & \multirow[t]{5}{*}{ Senang dengan pembelajaran di PPBA } & Sangat senang & 19 \\
\hline & & Senang & 14 \\
\hline & & Cukup Senang & 24 \\
\hline & & Kurang Senang & 8 \\
\hline & & Tidak Senang & 4 \\
\hline \multirow[t]{5}{*}{2} & \multirow{5}{*}{$\begin{array}{l}\text { Dosen selalu mengkreasikan pembelajaran di } \\
\text { PPBA }\end{array}$} & Selalu & 19 \\
\hline & & Sering & 12 \\
\hline & & Jarang & 15 \\
\hline & & Kadang-kadang & 4 \\
\hline & & Tidak pernah & 1 \\
\hline \multirow[t]{5}{*}{3} & \multirow[t]{5}{*}{ Jumlah mahasiswa setiap kelas sudah sesuai } & Sangat sesuai & 11 \\
\hline & & Sesuai & 20 \\
\hline & & Cukup sesuai & 16 \\
\hline & & Kurang sesuai & 2 \\
\hline & & Tidak sesuai & 2 \\
\hline \multirow[t]{5}{*}{4} & \multirow[t]{5}{*}{ Pengklasifikasian kelas sudah sesuai } & Sangat sesuai & 13 \\
\hline & & Sesuai & 16 \\
\hline & & Cukup sesuai & 12 \\
\hline & & Kurang sesuai & 9 \\
\hline & & Tidak sesuai & 1 \\
\hline \multirow[t]{5}{*}{5} & \multirow[t]{5}{*}{ Mendapatkan banyak tambahan materi di PPBA } & Sangat banyak & 14 \\
\hline & & Banyak & 13 \\
\hline & & Cukup banyak & 21 \\
\hline & & Kurang banyak & 0 \\
\hline & & Tidak banyak & 3 \\
\hline
\end{tabular}




\begin{tabular}{|l|l|l|}
\hline 6 & Tanggapan umum & $\begin{array}{l}\text { Pengajaran menggunakan } \\
\text { Bahasa Arab }\end{array}$ \\
\cline { 3 - 3 } & & Materi tentang sehari-hari \\
\cline { 3 - 3 } & $\begin{array}{l}\text { Pengajar lebih } \\
\text { mengkreasikan pembelajaran }\end{array}$ \\
\cline { 3 - 3 } & $\begin{array}{l}\text { Tepat waktu ketika mengajar } \\
\end{array}$ & $\begin{array}{l}\text { Mahasiswa seharusnya lebih } \\
\text { aktif dalam pembelajaran }\end{array}$ \\
\hline
\end{tabular}

Sementara Hasil observasi pada Tabel 2 tentang proses pembelajaran di PPBA ini, dilakukan selama satu bulan dengan tempat observasi adalah salah satu kelas yang mewakili semua program studi yang ada di Fakultas Agama Islam.

Tabel 2. Hasil Observasi Sebelum Pengembangan

\begin{tabular}{|c|c|c|}
\hline No & Poin yang diamati & Hasil Observasi \\
\hline 1 & $\begin{array}{l}\text { Suasana } \\
\text { Pembelajaran }\end{array}$ & 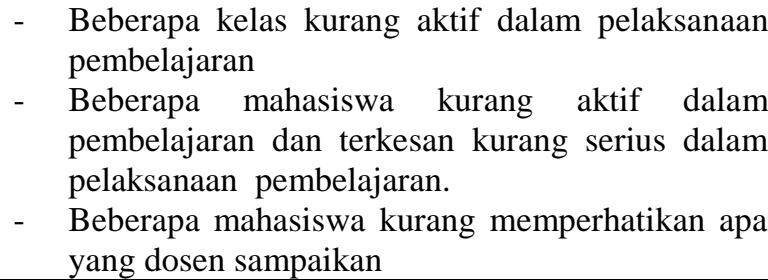 \\
\hline 2 & Model Pembelajaran & $\begin{array}{ll}\text { - } & \text { Pembelajaran mayoritas masih bersifat klasikal } \\
\text { - } & \text { Teacher center } \\
\text { - } & \text { Mahasiswa kurang aktif dalam pembelajaran } \\
\text { - } & \text { Dosen kurang memperhatikan keefektifan } \\
& \text { mahasiswa selama proses pembelajaran }\end{array}$ \\
\hline 3 & Klasifikasi kelas & $\begin{array}{l}\text { - Hampir di setiap kelas kemampuan mahasiswa } \\
\text { tidak merata } \\
\text { - Siswa yang kemampuannya tinggi kurang bisa } \\
\text { mendukung teman yang berkemampuan rendah. } \\
\text { - Mahasiswa yang kemampuannya rendah tidak } \\
\text { mendapat tambahan materi dan tertinggal materi. }\end{array}$ \\
\hline
\end{tabular}

Berdasarkan hasil observasi dan wawancara, peneliti mengembangkan model pembelajaran LCAL, dengan langkah-langkah dalam pelaksanaan pembelajaran bahasa Arab berbasis LCAL adalah:

1. Mengklasifikasikan kemampuan mahasiswa

2. Menentukan nilai untuk menetapkan kapabilitas siswa

3. Pembagian kelas berdasarkan hasil placement test. Setiap kelas terdapat 4-6 siswa yang mempunyai kemampuan berbahasa Arab.

4. Siswa di dalam kelas yang sudah ditentukan dibagi menjadi beberapa kelompok kecil.

5. Masing-masing kelompok terdiri dari 10 orang.

6. Struktur dalam kelompok terdiri dari tholib, musa'id, dan musyrif. 
- Tholib adalah mahasiswa pembelajar

- Musa'id adalah mahasiswa yang ditunjuk sebagai instruktur

- Musyrif adalah dosen pendamping

7. Sebelum melaksanakan pembelajaran, musyrif memberikan bimbingan materi dan teknik pembelajaran

8. Musyrif mendampingi dan melakukan evaluasi pembelajaran di akhir prosesnya.

Sementara hasil validasi dari para validator seperti pada tabel 3

Tabel 3. Hasil Validasi Ahli

\begin{tabular}{|c|c|c|}
\hline No & Validator Ahli & Catatan Validator \\
\hline 1 & $\begin{array}{l}\text { Dr. Abdul Haris, MA } \\
\text { (Universitas Muhammadiyah } \\
\text { Malang) }\end{array}$ & $\begin{array}{l}\text { - Perlu kejelasan tugas musaid dalam proses } \\
\text { pembelajaran } \\
\text { - Perlu kejelasan tahapan pembelajaran dan } \\
\text { timing-nya } \\
\text { - Perlu kejelasan tentang hal-hal yang harus dan } \\
\text { tidak boleh dilakukan dalam model } \\
\text { pembelajaran }\end{array}$ \\
\hline 2 & $\begin{array}{l}\text { Ahmad Fatoni, Lc., M.Ag } \\
\text { (Universitas Muhammadiyah } \\
\text { Malang) }\end{array}$ & $\begin{array}{l}\text { - Perlu kriteria untuk musaid } \\
\text { - Perlu diperjelas posisi dosen ketika } \\
\text { pembelajaran berlangsung } \\
\text { - } \text { Bagus dan lanjutkan }\end{array}$ \\
\hline 3 & $\begin{array}{l}\text { Dr. H. Muhammad Ahda } \\
\text { Arafat, M.A } \\
\text { (Dosen Universitas Terbuka } \\
\text { Pasuruan) }\end{array}$ & $\begin{array}{l}\text { - Model pembelajaran sudah sesuai dengan } \\
\text { model tutor sebaya } \\
\text { - Fungsi fasilitator perlu diperjelas } \\
\text { - } \text { Bisa dilanjutkan dengan perbaikan }\end{array}$ \\
\hline 4 & $\begin{array}{l}\text { Hermi Ismawati, S.S., } \\
\text { (Universitas Islam }\end{array}$ & $\begin{array}{l}\text { Model pembelajaran tutor sebaya intinya adalah } \\
\text { pada tutor (musaid) yang ditunjuk dan dianggap } \\
\text { sudah mampu oleh dosen untuk menerangkan } \\
\text { materi yang ada. } \\
\text { Dan tutor sebaya ini lebih efisien dikarenakan } \\
\text { pendalaman pembelajaran dalam bentuk } \\
\text { kelompok kecil, sehingga mahasiswa lebih } \\
\text { mudah untuk memahami. }\end{array}$ \\
\hline
\end{tabular}

Merujuk pada model pembelajaran di Program Pengembangan Bahasa Arab (PPBA) yang terjadi saat ini, dilihat dari hasil observasi dan jawaban angket dari para mahasiswa, disimpulkan bahwa perlu adanya kebijakan baru terkait dengan model pembelajaran. Pembelajaran yang ada saat ini, kebanyakan masih dengan pendekatan teacher center.

Hal tersebut benar terjadi dalam pembelajaran yang ada sekarang, para dosen yang mengajar kurang mengkreasikan metode pembelajaran. Dan para mahasiswa lebih sering langsung diminta untuk mengerjakan lembar latihan. Kemonotonannya dari pemilihan pembelajaran yang berbasis teacher center 
menimbulkan kebosanan di kalangan siswa. Seharusnya, untuk menjadi seorang guru tidak hanya menjadi seorang teacher tapi juga harus bisa mentouching siswa. Sehingga, apa yang disampaikan sampai sasaran dan tujuan.

Jika dihadapkan pada masa sekarang ini, teacher centered memang tidak cocok dengan karakteristik mahasiswa sekarang. Mahasiswa sekarang masuk pada generasi millennial, tidak bisa hanya duduk diam mendengarkan ceramah dari dosen. Karakteristik generasi millennial di antaranya (1) Sangat menghargai perbedaan, lebih memilih bekerja sama daripada menerima perintah, dan sangat pragmatis ketika memecahkan persoalan, (2) Memiliki rasa optimis yang tinggi, fokus pada prestasi, percaya diri, percaya pada nilai-nilai moral dan sosial, menghargai adanya keragaman. ${ }^{12}$

Dari karakter di atas, memang sangat tidak cocok dengan menggunakan teacher centered. Karena mahasiswa lebih suka juga diberikan tantangan untuk diselesaikan dalam kelompok. Dalam pembelajaran bahasa Arab, kreasi pola pembelajaran memang sangat dibutuhkan, karena sudah tarimage bahwa bahasa Arab itu sulit dipelajari. Prinsip manajemen dalam kelas adalah guru bertanggung jawab penuh terhadap semua aspek perencanaan, pelaksanaan,dan evaluasi proses pembelajaran. Untuk memastikan proses ini berjalan, guru akan mendelegasikan beberapa tanggung jawab tersebut kepada siswa atau asisten di beberapa kelas. ${ }^{13}$

Untuk menanggapi persoalan di atas, perlulah dikembangkan suatu model pembelajaran Little Circle Arabic Learning (LCAL). LCAL ini pengembangan dari model pembelajaran tutor sebaya, yang mana menjadikan siswa sebagai tutor dalam penyampaian materi pendidikan. Sehingga, nantinya di masing-masing kelas klasikal dimungkinkan adanya tiga siswa yang bisa dijadikan tutor. Skema pembelajaran LCAL sebagai berikut.

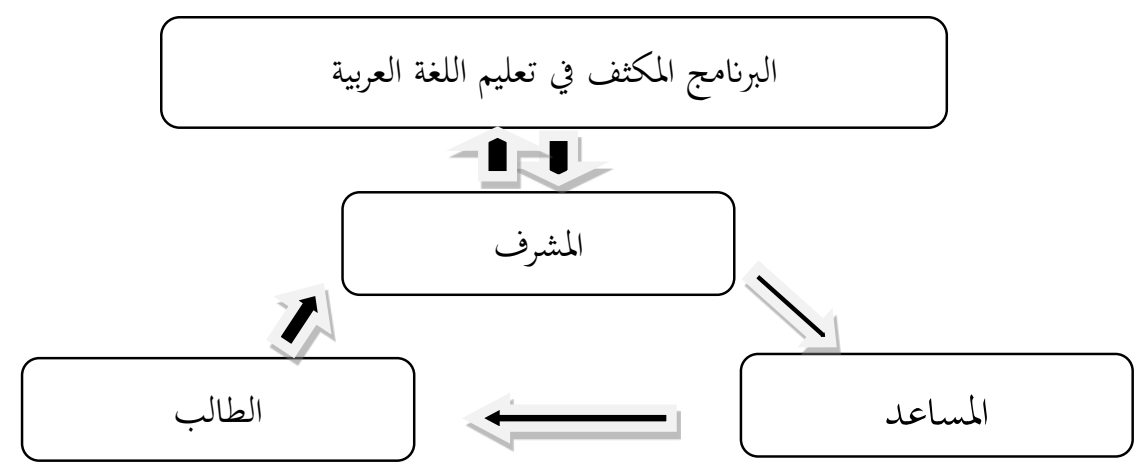

12 Yanuar Surya Putra, "Theoritical Review : Teori Perbedaan Generasi," Among Makarti 9, no. 18 (2017), https://jurnal.stieama.ac.id/index.php/ama/article/view/142.

${ }^{13}$ Fathur Rohman, "Strategi Pengelolaan Komponen Pembelajaran Bahasa Arab," Arabiyat : Jurnal Pendidikan Bahasa Arab Dan Kebahasaaraban 1, no. 1 (2014): 63-78, https://doi.org/10.15408/a.v1i1.1131. 
Skema di atas merupakan desain model pembelajaran LCAL setelah mendapat masukan dari para ahli. Sementara untuk penjelasan tugas terdapat pada tabel 4.

Tabel 4. Gambaran Tugas pada Elemen LCAL

\begin{tabular}{|c|c|c|}
\hline No & Nama Unit & Deskripsi Tugas \\
\hline 1 & $\begin{array}{l}\text { البرنامج المكثف في تعليم اللغة العربية } \\
\text { Program Pengembangan } \\
\text { Bahasa Arab (PPBA) } \\
\text { Unit di Fakultas Agama Islam } \\
\text { Universitas Muhammadiyah } \\
\text { Malang }\end{array}$ & $\begin{array}{ll}\text { - } & \text { Bertanggung jawab atas pembelajaran } \\
\text { Bahasa Arab untuk semua mahasiswa baru. } \\
\text { - } \begin{array}{l}\text { Mengawasi proses pelaksanaan model } \\
\text { pembelajaran }\end{array}\end{array}$ \\
\hline 2 & $\begin{array}{l}\text { Dosen yang mengajar pada } \\
\text { kelas dan fokus maharah }\end{array}$ & 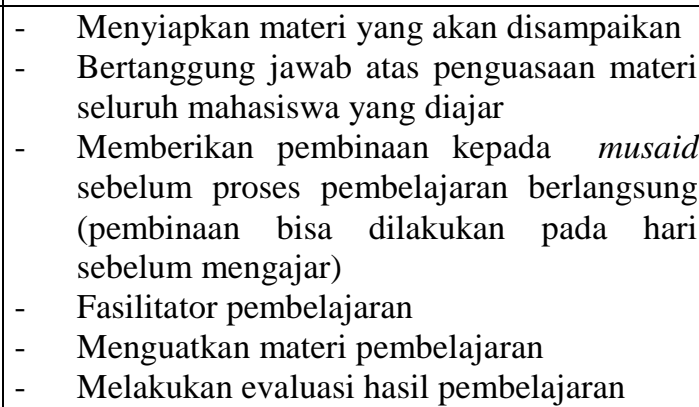 \\
\hline 3 & \begin{tabular}{l}
\multicolumn{1}{c}{ المساعد } \\
Mahasiswa yang ditunjuk \\
sebagai tutor dalam kelas \\
tersebut
\end{tabular} & 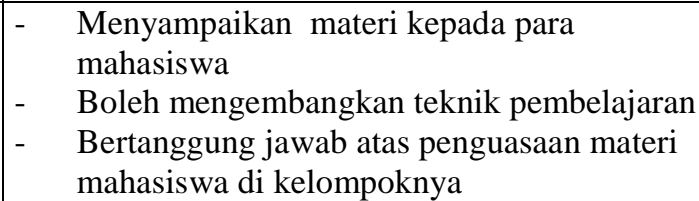 \\
\hline
\end{tabular}

Proses pelaksanaan model pembelajaran LCAL sebagai berikut ;

1. Mahasiswa pada kelas klasikal dibagi menjadi kelompok kecil.

2. Masing-masing kelompok maksimal terdiri dari 10 orang dan maksimal tiga kelompok dalam satu kali pembelajaran.

3. Struktur dalam kelompok terdiri dari tholib, musa'id, dan musyrif.

4. Tholib adalah mahasiswa pembelajar.

5. Musa'id adalah mahasiswa yang ditunjuk sebagai instruktur.

6. Musyrif adalah dosen pendamping.

7. Sebelum melaksanakan pembelajaran, musyrif memberikan bimbingan materi dan teknik pembelajaran.

8. Musaid menyampaikan materi yang sudah diberikan oleh musyrif.

9. Musaid boleh mengkreasikan teknik penyampaian materi.

10. Musaid mendampingi dan memastikan seluruh anggota kelompok memahami materi.

11. Musyrif menguatkan materi secara klasikal.

12. Musyrif mengevaluasi hasil pembelajaran melalui soal sederhana.

13. Musyrib melaporkan hasil pembelajaran kepada kepala PPBA. 
Adapun karakteristik mahasiswa yang dijadikan sebagai musaid adalah (1) Mempunyai kemampuan bahasa Arab yang lebih dibandingkan teman kelasnya, dibuktikan dengan hasil tes. (2) Mempunyai psikologis "ngayomi" dan telaten. (3) Bertanggung jawab terhadap tugas. Para tutor harus berusaha mendapatkan hubungan dan pergaulan baru yang baik dengan teman sebaya, mencari perannya sendiri, mengembangkan kecakapan intelektual dan sosial.

Bantuan belajar oleh teman sebaya dapat menghilangkan kecanggungan. Bahasa teman sebaya lebih mudah dipahami, selain itu dengan teman sebaya tidak ada rasa enggan, rendah diri, malu, dan sebagainya, sehingga diharapkan siswa yang kurang paham tidak segan-segan untuk mengungkapkan kesulitan-kesulitan yang dihadapinya, serta diperkuat dengan stimulus dari guru. ${ }^{14}$ Selain itu juga membuat mahasiswa bisa mengeksplor materi. ${ }^{15}$ Dari sini, model pembelajaran LCAL yang ditutori oleh temannya sendiri, diharapkan mampu membantu mahasiswa untuk lebih mudah mempelajari Bahasa Arab.

Selain karena mempermudah pencapaian target, model pembelajaran LCAL menuntut para dosen untuk lebih kreatif dalam perancangan pembelajaran. Dalam konteks pembelajaran bahasa Arab, upaya menginovasi dan mengkreasi pembelajaran merupakan ijtihad yang harus diperjuangkan. Ditengarai, bahwa sistem pembelajaran bahasa Arab yang digunakan masih belum mengarah pada penggunaan bahasa Arab sebagai alat komunikasi, melainkan lebih berbasis pada pengenalan bentuk-bentuk kaidah bahasa Arab yang lepas dari konteks. ${ }^{16}$

Aplikasi model pembelajaran LCAL akan sukses ketika para dosen nantinya mengimbanginya dengan metode pembelajaran yang inovatif. Keberhasilan penggunaan suatu metode merupakan keberhasilan proses pembelajaran yang pada akhirnya berfungsi sebagai determinasi kualitas pendidikan. ${ }^{17}$ Untuk itu, keberhasilan pelaksanaan model ini juga bergantung kepada pengajar.

${ }^{14}$ Miatin Rachmawati, Fitria Nugrahaeni, dan Lailatul Mauludiyah, "Improving Arabic Speaking Skill through Mind Mapping Strategy," Izdihar : Journal of Arabic Language Teaching, Linguistics, and Literature 3, no. 1 (2020): 31-44,

https://doi.org/10.22219/jiz.v3i1.10967.

${ }^{15}$ Mukhlison Effendi, “Integrasi Pembelajaran Active Learning Dan Internet-Based Learning Dalam Meningkatkan Keaktifan Dan Kreativitas Belajar," Nadwa 7, no. 2 (2016): 283-309, https://doi.org/10.21580/nw.2013.7.2.563.

${ }^{16}$ Moh Ainin, "Penelitian Pengembangan Dalam Pembelajaran Bahasa Arabi,"

OKARA: Jurnal Bahasa Dan Sastra 7, no. 2 (2013), http://ejournal.stainpamekasan.ac.id/index.php/okara/article/view/449.

${ }^{17}$ Sahkholid Nasution, "Metode Konvensional Dan Inkonvensional Dalam Pembelajaran Bahasa Arab," Jurnal Ilmiah Didaktika: Media IImiah Pendidikan Dan Pengajaran 12, no. 2 (2012), https://doi.org/10.22373/jid.v12i2.452. 


\section{E. Kesimpulan}

Desain model pembelajaran tutor sebaya yang dikembangkan melalui model Little Circle Arabic Learning (LCAL) untuk diterapkan dalam program pengembangan bahasa Arab terdiri dari musyrif, musaid, dan tholib. Ketiga komponen ini mempunyai tugas masing-masing yang saling mendukung keberhasilan pembelajaran Bahasa Arab. Musyrif sebagai penyedia materi dan rancangan pembelajaran serta evaluator pembelajaran. Musaid sebagai penyampai materi dan tombak utama penyampai materi. Sementara tholib sebagai penerima materi juga punya tanggung jawab untuk selalu aktif dalam mengikuti pembelajaran. Segitiga pembelajaran tersebut harus berkolaborasi dengan jelas sehingga bisa mampu menghasilkan pembelajaran yang efisien. Berdasarkan hasil validasi dari empat validator, metode Little Circle Arabic Learning (LCAL) jika dilaksanakan sesuai prosedur yang dibuat akan mampu meningkatkan motivasi dalam belajar. Sebab prinsip tutor sebaya memang untuk mempermudah siswa dalam belajar dengan tutor yang mudah berkomunikasi. Dan dengan adanya rumusan segitiga LCAL tersebut mampu menjadi salah satu solusi untuk pembelajaran bahasa Arab yang efisien. 


\section{Daftar Pustaka}

Ainin, Moh. "Penelitian Pengembangan Dalam Pembelajaran Bahasa Arabi."

OKARA: Jurnal Bahasa Dan Sastra 7, no. 2 (2013).

http://ejournal.stainpamekasan.ac.id/index.php/okara/article/view/449.

Ardi, Zadrian, Yulidar Ibrahim, dan Asrul Said. "Capaian Tugas Perkembangan Sosial

Siswa Dengan Kelompok Teman Sebaya Dan Implikasinya Terhadap

Program Pelayanan Bimbingan Dan Konseling." Konselor 1, no. 2 (2012).

https://doi.org/10.24036/0201212522-0-00.

Arjanggi, Ruseno, dan Titin Suprihatin. "Metode Pembelajaran Tutor Teman

Sebaya Meningkatkan Hasil Belajar Berdasar Regulasi-Diri." Makara

Human Behavior Studies in Asia 14, no. 2 (2010): 91-97.

https://doi.org/10.7454/mssh.v14i2.666.

Effendi, Mukhlison. "Integrasi Pembelajaran Active Learning Dan Internet-Based

Learning Dalam Meningkatkan Keaktifan Dan Kreativitas Belajar." Nadwa

7, no. 2 (2016): 283-309. https://doi.org/10.21580/nw.2013.7.2.563.

Indrianie, Niken Sholi. "Penerapan Model Tutor Sebaya Pada Mata Pelajaran

Bahasa Inggris Reported Speech Terhadap Hasil Belajar Peserta Didik MAN

Kota Probolinggo." Jurnal Kebijakan Dan Pengembangan Pendidikan 3, no.

1 (2015). http://ejournal.umm.ac.id/index.php/jkpp/article/view/2210.

Kurniawan, M. Arif, Agus Miftahillah, dan Nilna Milhatan Nasihah. "Pembelajaran

Berbasis Student-Centered Learning Di Perguruan Tinggi: Suatu Tinjauan Di

UIN Sunan Kalijaga Yogyakarta." Lentera Pendidikan : Jurnal IImu Tarbiyah

dan Keguruan 21, no. 1 (2018): 1-11.

https://doi.org/10.24252/lp.2018v21n1i1.

Muslim, Buhori. "Konsep Scientific Approach Dalam Pembelajaran Bahasa Arab Di

Perguruan Tinggi (Upaya Meningkatkan Produktivitas, Kreativitas dan

Inovasi Mahasiswa Dalam Pembelajaran)." LISANUNA: Jurnal IImu Bahasa

Arab dan Pembelajarannya 5, no. 1 (2016): 105. https://jurnal.ar-

raniry.ac.id/index.php/lisanuna/article/view/858.

Nasution, Sahkholid. "Metode Konvensional Dan Inkonvensional Dalam

Pembelajaran Bahasa Arab." Jurnal Ilmiah Didaktika: Media IImiah

Pendidikan Dan Pengajaran 12, no. 2 (2012).

https://doi.org/10.22373/jid.v12i2.452.

Noor, Fatwiah. "Kurikulum Pembelajaran Bahasa Arab di Perguruan Tinggi."

Arabiyatuna : Jurnal Bahasa Arab 2, no. 1 (2018): 1-22.

https://doi.org/10.29240/jba.v2i1.305.

Putra, Yanuar Surya. "Theoritical Review : Teori Perbedaan Generasi." Among

Makarti 9, no. 18 (2017).

https://jurnal.stieama.ac.id/index.php/ama/article/view/142.

Rachmawati, Miatin, Fitria Nugrahaeni, dan Lailatul Mauludiyah. "Improving Arabic

Speaking Skill through Mind Mapping Strategy." Izdihar : Journal of Arabic 
Language Teaching, Linguistics, and Literature 3, no. 1 (2020): 31-44. https://doi.org/10.22219/jiz.v3i1.10967.

Rohman, Fathur. "Strategi Pengelolaan Komponen Pembelajaran Bahasa Arab." Arabiyat : Jurnal Pendidikan Bahasa Arab Dan Kebahasaaraban 1, no. 1 (2014): 63-78. https://doi.org/10.15408/a.v1i1.1131.

Roscoe, Rod D., dan Michelene T. H. Chi. "Understanding Tutor Learning: Knowledge-Building and Knowledge-Telling in Peer Tutors' Explanations and Questions:" Review of Educational Research 77, no. 4 (2007). https://doi.org/10.3102/0034654307309920.

Ulfah, Maria. “Optimalisasi Hasil Belajar IPA Tentang Sistem Gerak Pada Manusia Melalui Metode Diskusi Dengan Tehnik Pembelajaran Tutor Sebaya." Jurnal Pendidikan Tindakan Kelas 3, no. 1 (2012). https://irpp.com/index.php/dinamika/article/view/5.

Yusuf, Syamsu. Psikologi Perkembangan Anak Dan Remaja. Bandung: PT. Remaja Rosda Karya, 2011. 
70 | Lailatul Mauludiyah 